\title{
Determination of Physical and Bacteriological Quality of Water Based on Most Probable Number (MPN) Count, pH and Total Hardness of Water Sources in and around Jabalpur City of Madhya Pradesh, India
}

\author{
Kashikar Supriya Satish*, Bhavana Gupta, Ran Vijay Singh, \\ Bhavana Rani and Shakuntala Birla
}

Narayani Niwas, Trimurti Nagar, Near Gajanan Maharaj Temple, Parbhani (MS), India

*Corresponding author

\section{A B S T R A C T}

\section{Keywords \\ Physical and bacteriological quality, Water, MPN count, Jabalpur city \\ Article Info \\ Accepted: \\ 20 June 2018 \\ Available Online: \\ 10 July 2018}

A study was designed with an objective to determine the safety of water for drinking or food preparation. The physical quality was checked on the basis of $\mathrm{pH}$ and total hardness. Out of 117 samples tested, $40(34.18 \%)$ were satisfactory i.e., MPN count between 1 and 3. Forty $(34.18 \%)$ were suspicious and rest $37(31.62 \%)$ were unsatisfactory. $111(94.87 \%)$ samples had $\mathrm{pH}$ in the range of $6.5-8.5$, remaining $6(5.12 \%)$ had $\mathrm{pH}>8$. Of 117 samples tested, none of the samples were soft or moderately hard, 72 $(61.53 \%)$ were hard (3-6 mEQ/L) and 45 (38.46\%) were very hard (>6

\section{Introduction}

Water is an "Elixir of Life". It plays a significant role in the sound health of every individual and is essential for plant and animal life also. Water contributes in a number of ways to the health, progress and enjoyment of living beings. It is having important functions like universal solvent, thermoregulation of body, maintenance of blood and plasma volumes, cellular osmotic pressure and assist in secretary and excretory functions of body. Thus, water is an essential element for life on earth.
It is facing a severe threat due to pollution. Now days, there is a growing concern among public health agencies from both developed and developing countries that zoonotic pathogens in livestock exert a pose to an unacceptable waterborne public health risk. Maheshwari (2008) tells that poor sanitary practices lead to the growth of pathogens such as Campylobacter jejuni, enterotoxigenic Escherichia coli, Salmonella spp, Shigella spp, Vibrio cholera, etc. causing mild to severe fatal form of diarrhea

Total coliform count i.e. most probable number count (MPN) is used to assess 
contamination level of drinking and swimming waters with fecal and sewage material. It also indicates presence of intestinal origin pathogens. Enumeration of coliforms as a water quality monitoring method involves inoculating a series of tubes containing MacConkey lactose broth with appropriate decimal dilutions; coliform bacteria present in the water sample multiply and are detected by formation of acid and gas as described by Cruickshank et al (1975).

The optimum $\mathrm{pH}$ is necessary for all stages of water treatment i.e., clarification and disinfection. For chlorination, $\mathrm{pH}$ should be less than 8.0. Further, if $\mathrm{pH}$ of water is not optimum, it may leads to corrosion of pipes in house hold as well as industrial supply, so this may alters taste, odour and appearance of water. The lower $\mathrm{pH}$ of water may also cause gastric disorder like acidity in humans and animals. $\mathrm{pH}$ of water may vary according to temperature, composition of water and material used for manufacturing distribution system in public supply. Health based guideline for $\mathrm{pH}$ proposed by WHO (2011) is between 6.5 and 8.5 with no relaxation. The hardness of water is also a important criteria to check its potability. The hardness of water is also depending upon geological formation of crust because the minerals in soil are getting dissolved in water during flow of stream, percolation, etc. Hard water can pose serious problems in industrial settings because it may leads to breakdowns of costly boilers, cooling towers, and other equipment. In domestic use also hard water have low leather formation ability when soap is agitated in water. It may form lime scale in kettles and water heaters.

Jabalpur is an important trade, commerce, industrial, educational and administrative centre of regional and national importance. It is the third largest city of Madhya Prdesh province as per the report of Indian population (2017). Good water resources are located around Jabalpur like river Narmada and many ponds, which are sources of animals and human consumption. River Narmada and ponds around Jabalpur receive a large amount of domestic wastes, sewage, agricultural and industrial effluents. An immediate attention is therefore required to determine the physical and bacteriological quality of water resources of Jabalpur District.

\section{Materials and Methods}

\section{Collection of samples}

Total of 117 samples were collected from different sources of water in Jabalpur city consisting of 20 samples each of different banks of river Narmada and public taps, 21 from tube wells, 35 samples of ponds, 21 samples of hand pumps (Table 1-6).

Approximately $100 \mathrm{ml}$ of water samples were collected from ponds, different banks of Narmada river, hand pumps, tube wells and public taps of Jabalpur city, in sterile bottles and brought to laboratory under sterile conditions on ice for bacteriological examination as described by Khadse (2010).

\section{Bacteriological quality of water by most probable number count}

Three tube set in triplicate were used. The first, second and third set of tube had taken 10 $\mathrm{ml}$ double strength MacConkey lactose broth, $5 \mathrm{ml}$ single strength MacConkey lactose broth and $5 \mathrm{ml}$ single strength MacConkey lactose broth respectively. The water sample of amount $10 \mathrm{ml}, 1 \mathrm{ml}$ and $0.1 \mathrm{ml}$ were added in respective first, second and third set of tube followed by incubation at $37^{\circ} \mathrm{C}$ for $24-48 \mathrm{hrs}$. and then observing production of gas and change in colour of the medium. The count was made by using McCrady table according to method described by Cruickshank et al., (1975). 


\section{Physical quality of water by pH}

To determine the $\mathrm{pH}$, the commercially available strips were dipped in the water sample and then immediately held it up against the colour indicator chart provided with the strips and the reading was noted.

\section{Physical quality of water by total hardness}

The water samples were collected and $100 \mathrm{ml}$ volume was transferred in a conical flask. Two $\mathrm{ml}$ of ammonia buffer solution and $8-10$ drops of colour indicator i.e., Eriochrome Black $\mathrm{T}$ was added to it and mixed thoroughly. The solution was titrated against N/50 EDTA till the colour of water turns blue.

The hardness was calculated as per the formula given by International Standards (2002).

\section{Results and Discussion}

Water is one of the prime elements responsible for life on earth. Due to various anthropogenic activities, water bodies gets contaminated by various microorganism (viz. pathogenic bacteria, viruses and parasites, etc), wide spectrum of chemicals like heavy metals, pesticides, toxins, drug residues, antibiotics. Physical changes such as elevated temperature, discoloration, change in $\mathrm{pH}$ and hardness may also make water unfit for life process as well as for other domestic uses. The results obtained were not indicating satisfactory potability of water. Therefore, there is need for regular monitoring of physico - chemical and biological parameters before as well as treatment before it is used for drinking, domestic, agricultural or industrial purposes. So, the present study was done to observe the water quality in Jabalpur.

In the present study, Out of 117 samples tested, $40(34.18 \%)$ were satisfactory result i.e., most probable number (MPN) count between 1 and 3 . Forty (34.18\%) were suspicious and rest $37(31.62 \%)$ were unsatisfactory as per recommendations given by CPCB (2011). Eleven (55\%) samples from different banks of river Narmada were satisfactory, whereas 5 (25\%) and $4(20 \%)$ were suspicious and unsatisfactory, respectively. Five (14.28\%), 14 (40\%) and 16 $(45.71 \%)$ samples of ponds were satisfactory, suspicious and unsatisfactory respectively. 10 (47.61\%), 7 (33.33\%) and 4 (19.04\%) samples from hand pumps were suspicious and unsatisfactory, respectively. From all the 21 samples of tube well, 7 (33.33\%) samples were satisfactory, $10(47.61 \%)$ suspicious and $4(19.04 \%)$ samples were unsatisfactory. In case of public tap water samples, 7 (35.00\%) were satisfactory, $4(20.00 \%)$ were suspicious and $9(45.00 \%)$ samples were found to be unsatisfactory as shown in table 7 .

Enumeration of coliforms as a water quality monitoring method involves inoculating a series of tubes containing MacConkey lactose broth with appropriate decimal dilutions; coliform bacteria present in the water sample multiply and are detected by formation of acid and gas. The present study was designed to detect the coliforms bacteria in water samples and to determine the water supply system being operated correctly and safe water for drinking or food preparation. During present study, the coliform bacteria have been found in all kinds of samples tested. Out of 117 samples tested, $40 \quad(34.18 \%)$ showed satisfactory result i.e., MPN count $<3,38$ $(32.47 \%)$ were suspicious and rest 39 $(33.33 \%)$ were unsatisfactory as per recommendations given by CPCB (2011). As per FAO, recommended MPN values for drinking water is $2 / 100 \mathrm{ml}$ and permissible limit for drinking water by WHO and BIS is $10 / 100 \mathrm{ml}$. The present study displayed range of MPN index from <3 to >2400. Similar study have conducted by Shafi et al., (2013) to 
assess water quality of Manasbal Lake of Kashmir and also got variable range between 4 and 460 MPN / $100 \mathrm{ml}$. None of the sample was found to be fit for drinking purpose and $5.00 \%$ samples were unfit for even domestic and recreational use also. Our results also showed similarity, wherein, 7 (5.98\%) samples were found unfit for bathing and swimming, $4(57.14 \%)$ of which are from ponds. Bacteriological analysis of drinking water in western Uttar Pradesh, by Kumar and Kumar (2013) revealed that MPN was very high $(\geq 180)$ in $58(50.00 \%), 32(28.00 \%)$ and $26(22.00 \%)$ of municipal tap water, government hand pumps and water cooler, respectively. Presence of coliform in all the categories indicates that consumption of such type of water may lead to different types of diseases especially of intestinal pathogens. Coliform presence in surface water (river and ponds) indicates contamination of water resources by surface runoff, direct disposal of untreated domestic and municipal wastes, sewage and animal excreta. The water contamination from hand pumps, tube wells and public taps indicates cross contamination of water distribution lines and system with nearby sewer line.

Out of 117 water samples tested, 111 $(94.87 \%)$ samples had $\mathrm{pH}$ in the range of 6.5 -
8.5 , remaining $6(5.12 \%)$ had $\mathrm{pH}>8.5$. All the samples from different banks of river Narmada were in range of 6.5-8.5. Out of 35 samples of ponds, $32(91.42 \%), 3(8.58 \%)$ had $\mathrm{pH}$ in range of 6.5-8.5 and >8.5, respectively. Nineteen $(90.47 \%)$ samples of hand pumps had $\mathrm{pH}$ range of $6.5-8.5$ and 2 (9.52\%) samples had $>8.5$. Among 21 samples of tube well, $20(95.23 \%)$ had a range of 6.5-8.5 and 1 $(4.76 \%)$ showed $\mathrm{pH}>8.5$. All the $20(100 \%)$ samples of public taps were in range of 6.58.5 , as shown in table 8 .

Similar results for $\mathrm{pH}$ are also reported by Rokade and Ganeshwade (2005) where they didn't get any sample exceeding $\mathrm{pH}>8.5$. $\mathrm{pH}$ of water may vary according to temperature, composition of water and material used for manufacturing distribution system in public supply. Health based guideline for $\mathrm{pH}$ proposed by WHO (2011) is between 6.5 and 8.5 with no relaxation. The optimum $\mathrm{pH}$ is necessary for all stages of water treatment i.e., clarification and disinfection. For chlorination, $\mathrm{pH}$ should be less than 8.0. Further, if $\mathrm{pH}$ of water is not optimum, it may leads to corrosion of pipes in house hold as well as industrial supply, so this may alters taste, odour and appearance of water. The lower $\mathrm{pH}$ of water may also cause gastric disorder like acidity in humans and animals.

Table.1 Samples from different water sources

\begin{tabular}{|c|l|c|}
\hline S.No. & Source of water sample & Total no. \\
\hline 1. & Different banks of river Narmada & 20 \\
\hline 2. & Ponds & 35 \\
\hline 3. & Hand pumps & 21 \\
\hline $\mathbf{4 .}$ & Tube wells & 21 \\
\hline $\mathbf{5 .}$ & Public taps & 20 \\
\hline & Total & $\mathbf{1 1 7}$ \\
\hline
\end{tabular}


Table.2 Samples from different banks of river Narmada

\begin{tabular}{|c|l|l|c|l|}
\hline S.No & Sample & Sample source & Number of samples & $\begin{array}{l}\text { Total } \\
\text { samples }\end{array}$ \\
\hline $\mathbf{1}$ & $\begin{array}{l}\text { Different banks of } \\
\text { river Narmada }\end{array}$ & Bheda ghat & 07 & \\
\cline { 3 - 4 } & & Gwari ghat & 07 & \multirow{2}{*}{20} \\
\hline & Tilwara ghat & 02 & \\
\cline { 3 - 4 } & & Lamhaita ghat & 03 & \\
\hline & & Jilhari ghat & 01 & \\
\hline
\end{tabular}

Table.3 Samples from ponds

\begin{tabular}{|c|c|c|c|c|c|}
\hline \multirow[t]{2}{*}{ S.No. } & \multirow[t]{2}{*}{ Sources } & \multicolumn{3}{|c|}{ Collection Period } & \multirow{2}{*}{$\begin{array}{l}\text { Total } \\
\text { samples }\end{array}$} \\
\hline & & $\begin{array}{l}\text { Pre } \\
\text { Ganesha }\end{array}$ & $\begin{array}{l}\text { Post } \\
\text { Ganesha }\end{array}$ & Random & \\
\hline 1 & Hanuman tal & 01 & 01 & 01 & 03 \\
\hline 2 & Gulawwa tal & 01 & 01 & 01 & 03 \\
\hline 3 & Dev tal & 01 & 01 & 01 & 03 \\
\hline 4 & Mahanadda tal & 01 & 01 & 01 & 03 \\
\hline 5 & Balasagar tal & 01 & 01 & 01 & 03 \\
\hline 6 & Shani kund & 01 & 01 & 01 & 03 \\
\hline 7 & Lal baba tal & 01 & 01 & 01 & 03 \\
\hline 8 & Imrati tal & 01 & 01 & 01 & 03 \\
\hline 9 & Supa tal & 00 & 00 & 03 & 03 \\
\hline 10 & Bhairav nagar & 00 & 00 & 03 & 03 \\
\hline 11 & Kal bhairav tal & 00 & 00 & 03 & 03 \\
\hline 12 & Prakash colony & 00 & 00 & 01 & 01 \\
\hline 13 & Rani Durgawati fort & 00 & 00 & 01 & 01 \\
\hline & Total & 08 & 08 & 19 & 35 \\
\hline
\end{tabular}

Table.4 Samples from hand pumps

\begin{tabular}{|c|l|l|c|}
\hline S. No & Sample & Sample source & Number of samples \\
\hline 1 & Hand pumps & Different places in Jabalpur city & 21 \\
\hline
\end{tabular}

Table.5 Samples from tube wells

\begin{tabular}{|r|l|l|c|c|}
\hline $\begin{array}{l}\text { S. } \\
\text { No }\end{array}$ & Sample & Sample source & $\begin{array}{l}\text { Number of } \\
\text { samples }\end{array}$ & $\begin{array}{l}\text { Total } \\
\text { samples }\end{array}$ \\
\hline $\mathbf{1}$ & \multirow{2}{*}{ Tube wells } & Public Place & 05 & 21 \\
\cline { 1 - 2 } $\mathbf{2}$ & & Hotels & 07 & \\
\hline $\mathbf{3}$ & & Residence & 05 & \\
\hline $\mathbf{4}$ & & Hospital & 01 & \\
\hline
\end{tabular}




\begin{tabular}{|c|c|c|c|c|}
\hline 5 & & College & 03 & \\
\hline \multicolumn{5}{|c|}{ Table.6 Samples from public taps } \\
\hline $\begin{array}{l}\text { S. } \\
\text { No. }\end{array}$ & Sample & Sample source & $\begin{array}{l}\text { Number of } \\
\text { samples }\end{array}$ & $\begin{array}{l}\text { Total } \\
\text { samples }\end{array}$ \\
\hline 1 & Public Taps & $\begin{array}{l}\text { Different regions of } \\
\text { Jabalpur }\end{array}$ & 20 & 20 \\
\hline
\end{tabular}

Table.7 Most probable number count of different water sources

\begin{tabular}{|c|c|c|c|c|c|c|c|}
\hline \multicolumn{2}{|c|}{ Sr. No. } & 1 & 2 & 3 & 4 & 5 & Total \\
\hline \multicolumn{2}{|c|}{$\begin{array}{c}\text { Sample source (No. Of } \\
\text { Samples }\end{array}$} & $\begin{array}{l}\text { Different } \\
\text { banks of }\end{array}$ & $\begin{array}{c}\text { Ponds } \\
(35)\end{array}$ & $\begin{array}{l}\text { Hand } \\
\text { pump }\end{array}$ & $\begin{array}{c}\text { Tube } \\
\text { wells }(21)\end{array}$ & $\begin{array}{l}\text { Public } \\
\text { taps (20) }\end{array}$ & 117 \\
\hline \multirow{8}{*}{$\begin{array}{c}\text { Grading } \\
\text { (Coliform/ } \\
100 \mathrm{ml})\end{array}$} & $\begin{array}{l}\text { I Excellent } \\
(01)\end{array}$ & 00 & 00 & 00 & 00 & 00 & 00 \\
\hline & Percentage & 00.00 & 00.00 & 00.00 & 00.00 & 00.00 & 00.00 \\
\hline & $\begin{array}{c}\text { II } \\
\text { Satisfactory } \\
(1-03)\end{array}$ & 11 & 05 & 10 & 07 & 07 & 40 \\
\hline & Percentage & 55.00 & 14.28 & 47.61 & 33.33 & 35.00 & 34.18 \\
\hline & $\begin{array}{l}\text { III Suspicious } \\
(4-10)\end{array}$ & 05 & 14 & 07 & 10 & 04 & 40 \\
\hline & Percentage & 25.00 & 40.00 & 33.33 & 47.61 & 20.00 & 34.18 \\
\hline & $\begin{array}{c}\text { IV } \\
\text { Unsatisfactory } \\
(>10)\end{array}$ & 04 & 16 & 04 & 04 & 09 & 37 \\
\hline & Percentage & 20.00 & 45.71 & 19.04 & 19.04 & 45.00 & 31.62 \\
\hline
\end{tabular}

Table. $8 \mathrm{pH}$ of different water resources

\begin{tabular}{|c|c|c|c|c|c|c|}
\hline \multirow{2}{*}{$\begin{array}{l}\text { S. } \\
\text { No. }\end{array}$} & \multirow[t]{2}{*}{ Samples tested } & \multirow{2}{*}{$\begin{array}{l}\text { Number of } \\
\text { samples }\end{array}$} & \multicolumn{2}{|c|}{$6.5-8.5$} & \multicolumn{2}{|c|}{$>8.5$} \\
\hline & & & $\begin{array}{l}\text { Number of } \\
\text { positive } \\
\text { samples }\end{array}$ & $\begin{array}{l}\text { Percentage } \\
\text { of positive } \\
\text { samples }\end{array}$ & $\begin{array}{l}\text { Number of } \\
\text { positive } \\
\text { samples }\end{array}$ & $\begin{array}{l}\text { Percentage } \\
\text { of positive } \\
\text { samples }\end{array}$ \\
\hline 1 & $\begin{array}{l}\text { Different banks } \\
\text { of river Narmada }\end{array}$ & 20 & 20 & 100.00 & 00 & 00.00 \\
\hline 2 & Ponds & 35 & 32 & 91.42 & 03 & 08.58 \\
\hline 3 & Hand pumps & 21 & 19 & 90.47 & 02 & 09.52 \\
\hline 4 & Tube wells & 21 & 20 & 95.23 & 01 & 04.76 \\
\hline 5 & Public taps & 20 & 20 & 100.00 & 00 & 00.00 \\
\hline & Total & 117 & 111 & 94.87 & 06 & 05.12 \\
\hline
\end{tabular}


Int.J.Curr.Microbiol.App.Sci (2018) 7(7): 2970-2978

Table.9 Total hardness of different water sources

\begin{tabular}{|c|c|c|c|c|c|c|c|c|c|c|}
\hline \multirow[t]{2}{*}{$\begin{array}{l}\text { S. } \\
\text { No. }\end{array}$} & \multirow[t]{2}{*}{ Sample source } & \multirow[t]{2}{*}{$\begin{array}{l}\text { Number of } \\
\text { samples }\end{array}$} & \multicolumn{2}{|c|}{$\begin{array}{c}\text { Soft } \\
(<1 \mathrm{mEQ} / \mathrm{L})\end{array}$} & \multicolumn{2}{|c|}{$\begin{array}{c}\text { Moderately Hard } \\
\text { (1 - } 3 \mathrm{mEQ} / \mathrm{L})\end{array}$} & \multicolumn{2}{|c|}{$\begin{array}{c}\text { Hard } \\
(3-6 \mathrm{mEQ} / \mathrm{L})\end{array}$} & \multicolumn{2}{|c|}{$\begin{array}{c}\text { Very Hard } \\
\text { (>6 mEQ/L) }\end{array}$} \\
\hline & & & $\begin{array}{l}\text { Number of } \\
\text { positive } \\
\text { samples }\end{array}$ & $\begin{array}{l}\text { Percentage } \\
\text { of positive } \\
\text { samples }\end{array}$ & $\begin{array}{l}\text { Number of } \\
\text { positive } \\
\text { samples }\end{array}$ & $\begin{array}{l}\text { Percentage } \\
\text { of positive } \\
\text { samples }\end{array}$ & $\begin{array}{l}\text { Number of } \\
\text { positive } \\
\text { samples }\end{array}$ & $\begin{array}{l}\text { Percentage } \\
\text { of positive } \\
\text { samples }\end{array}$ & $\begin{array}{l}\text { Number of } \\
\text { positive } \\
\text { samples }\end{array}$ & $\begin{array}{l}\text { Percentage of } \\
\text { positive } \\
\text { samples }\end{array}$ \\
\hline 1 & $\begin{array}{l}\text { Different banks } \\
\text { of river Narmada }\end{array}$ & 20 & 00 & 00.00 & 00 & 00.00 & 20 & 100.00 & 00 & 00.00 \\
\hline 2 & Ponds & 20 & 00 & 00.00 & 00 & 00.00 & 35 & 10.00 & 00 & 00.00 \\
\hline 3 & Hand pumps & 21 & 00 & 00.00 & 00 & 00.00 & 02 & 09.52 & 19 & 90.47 \\
\hline 4 & Tube wells & 21 & 00 & 00.00 & 00 & 00.00 & 02 & 09.52 & 19 & 90.47 \\
\hline \multirow[t]{2}{*}{5} & Public taps & 20 & 00 & 00.00 & 00 & 00.00 & 13 & 65.00 & 07 & 35.00 \\
\hline & Total & 117 & 00 & 00.00 & 00 & 00.00 & 72 & 61.53 & 45 & 38.46 \\
\hline
\end{tabular}


Out of 117 samples tested, none of the samples were soft or moderately hard, 72 $(61.53 \%)$ were hard (3 - $6 \mathrm{mEQ} / \mathrm{L})$ and 45 $(38.46 \%)$ were very hard $(>6 \mathrm{mEQ} / \mathrm{L})$. All the samples from different banks of river Narmada 20 (100.00\%) and ponds 35 $(100.00 \%)$ were hard (3 - $6 \mathrm{mEQ} / \mathrm{L})$. Two $(9.52 \%)$ samples of hand pumps were hard and rest $19(90.47 \%)$ samples were very hard. Among 21 samples of tube wells, 2 (9.52\%) and $19(90.47 \%)$ were hard and very hard, respectively. Thirteen (65\%) samples of public taps were hard and remaining 7 (35\%) were very hard, as depicted in table 9 .

Ramya et al., (2015) estimated total hardness of ground water from a town and two different villages of Andhra Pradesh and revealed that out of 120 samples tested, 39 (32.50\%) samples were moderately hard, 76 $(63.33 \%)$ samples were hard water and 5 $(4.16 \%)$ samples had very hard water. In our study, comparatively higher percentage $(38.46 \%)$ of very hard water was observed and it may be attributed to ground water resources like hand pumps and tube wells, which were contributing $84.44 \%$. The results revealed that surface water resources (different banks of river Narmada and ponds) were having hard water. The hardness of water is also depending upon geological formation of crust because the minerals in soil are getting dissolved in water during flow of stream, percolation, etc.

The acceptable limit given by BIS (2009) is 4 $\mathrm{mEQ} / \mathrm{L}$ and permissible limit in the absence of alternate source is $12 \mathrm{mEQ} / \mathrm{L}$. In this study out of 117 samples 37 (31.62\%), 57 (48.71\%) and $23(19.65 \%)$ had total hardness <4 $\mathrm{mEQ} / \mathrm{L}, 4-12 \mathrm{mEQ} / \mathrm{L}$ and $>12 \mathrm{mEQ} / \mathrm{L}$, respectively. $23.80 \%$ samples from hand pumps, $66.66 \%$ of tube wells and $20.0 \%$ of public taps had total hardness $>12 \mathrm{mEQ} / \mathrm{L}$.

Very hard water (>6 mEQ/L) may be harmful for health. It may aggravate eczema. Hard water may consume more soap and results in soap salt residues on the skin and on clothes which are not easily rinsed off and lead to contact irritation as per Thomas \& Sach (2000). Excessively hard water can also have corrosion tendencies which can be associated with health risks due to leaching effect on lead, copper and other metals. It may also reduce lifespan of the distribution pipes and system, as information given by WHO (2011).

\section{Acknowledgement}

It gives me immense pleasure and proud to express my deep sense of sincere gratitude to my research guide Dr. Bhavana Gupta, Asst.Prof. Dept. of Veterinary Public Health and Epidemiology, College of Veterinary Science and Animal Husbandry NDVSU, Jabalpur for her invaluable support, encouragement and remarkable guidance. I would like to thank Dr. Ran Vijay Singh, Incharge of the department of Veterinary Public Health and Epidemiology, College of Veterinary Science and Animal Husbandry NDVSU, Jabalpur. My friends Dr. Shakuntala Birla, Dr. Vijaya Thakur and Dr. Sujata Merawi for their keen interest in my research work.

\section{References}

Cruickshank, R., Duguid, J.P., Marmion, B.P. and Swain, R.H.A. 1975. Medical Microbiology, $12^{\text {th }}$ Edn., Crurchii Livingstone Edinburgh, pp 278.

BIS 2009. Drinking Water Specification Online http://bis.org.in/sf/fad/FAD25(2047) C. pdf

CPCB 2011. Guide Manual: Water and Waste Water Analysis online http://cpcb.nic.in/upload/NewItems/N ewItem_171_guidemanualw\&wwanal ysis.pdf

Indian Population 2017. Population of 
Jabalpur. Online Indian population2017.in/population -ofjabalpur-2017.html.

Indian Standards 2002. Determination of Total Hardness online http://nitttrc.ac.in/Four\%20quadrant/e el/Quadrant\%20\%201/exp5_pdf.pdf.

Khadse, G.K. 2010. Collection and preservation of samples and field analysis. In: Training programme on quality assurance and quality control in water quality monitoring and assessment, Nagpur, 21- 22, October 2010, National Environmental Engineering Research Institute, pp 1 32.

Kumar, M. and Kumar, R. 2013. Assessment of physico - chemical properties of ground water in granite mining area in Goramachia, Jhansi, UP, India. International Research Journal of Environment Sciences, 2(1): 19-24.

Maheshwari, N. 2008. Clinical Microbiology and Parasitology. $2^{\text {nd }}$ Edn., Jaydeep Brothers Medical Publishers, New Delhi, India, pp 272.

Ramya, P., Reddy, E.T. and Rao, L.V. 2015. A study on the estimation of hardness in ground water samples by EDTA tritrimetric method. International Journal of Recent Scientific Research, 6: 4505-4507.

Rokade, P.B. and Ganeshwade, R.M. 2005. Impact of pollution on water quality of Salim Ali lake at Aurangabad, Uttar Pradesh. Journal of Zoology, 25(2): 219-220.

Shafi, S., Kamili, A.N., Shah, M.A. and Bandh, S.A. 2013. Coliform bacterial estimation: A tool for assessing water quality of Manasbal lake of Kashmir, Himalaya. African Journal of Microbiology Research, 7(31): 39964000.

Thomas, K.S. and Sach, T.H. 2000. A multicentre randomized controlled trial of ion - exchange water softeners for the treatment of eczema in children: protocol for the softened water eczema trial. British Journal of Dermatology, 159(3): 561-566.

WHO 2011. Hardness in Drinking - Water Background document for development of WHO Guidelines for Drinking - Water Quality, pp 1-19.

\section{How to cite this article:}

Kashikar Supriya Satish, Bhavana Gupta, Ran Vijay Singh, Bhavana Rani and Shakuntala Birla. 2018. Determination of Physical and Bacteriological Quality of Water Based on Most Probable Number (MPN) Count, $\mathrm{pH}$ and Total Hardness of Water Sources in and around Jabalpur City of Madhya Pradesh, India. Int.J.Curr.Microbiol.App.Sci. 7(07): 2970-2978. doi: https://doi.org/10.20546/ijcmas.2018.707.347 